\title{
無撚糸織物の引張り強さについて
}

\author{
岐鼻大学工業短期大学部 渡辺明 \\ 岐阜大学工学部黑崎新也 - 近田冨士雄
}

\section{THE ASPECT OF TENSILE STRENGTH OF TWISTLESS-YARN FABRIC}

\author{
By Akira Watanabe*, Shinya Kurosaki** and Fujio Konda** \\ * (Junior Technical college, Gifu University, Kakamigahara City, \\ Gifu Prefecture, Japan) \\ ** (Faculty of Engineering, Gifu University, Kakamigahara City, \\ Gifu Prefecture, Japan)
}

Recently, several kinds of twistless-yarns (Tex-Ja Yarn, Bob-Tex Yarn, T.N.O. Yarn etc.) and their fabrics have been developed. This paper reprts on the breaking strength of twistless-yarn fabrics. The twistlessyams $\left(T_{0}\right)$ were produced by means of the apparatus shown in Fig. 1 . The conventional yarns $\left(T_{2.5}\right.$ and $\left.T_{6.5}\right)$ of twist factors $2.5,6.5$ were produced by ring frame. They were then woven into fabrics and washed to remove the adhesive. These fabrics are named, $T_{0}$ Fabric, $T_{2,5}$ Fabric and $T_{6.5}$ Fabric respectively. Their loadelongation curves are shown in Fig. 6. Defferent yarn densities of the $T_{0}$ and $T_{2.5}$ Fabrics are shown in Table 2, and their load-elongation curves are shown in Fig. 7 and Fig. 8. The breaking strength per yarn in fabric are given in Fig. 9 and Fig. 10, for comparison.

When the twistless-yarn fabric is elongated, compressive forces work at the intersecting points of the yarn in the fabric, and therefore inter-fiber frictional force increases. From this point of view, the compressive forces at one of the intersecting points of the yarns in fabric were calculated. (formula (3) (4) and Fig. 15) Futhermore, from the relationship between the inter-fibre frictional force and the yarn strength, the breaking strength per yam in the fabric was calculated and the calculated values are compared with the experimental data.

(Received September 13, 1972)

\section{1. 緒}

言

近年，無然䒺㧍よび無然系織物が新しく登場 し; 注目 されている。この無然系は1955年のTex-Ja 系 ${ }^{1)}$ 始ま

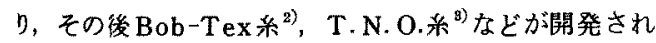
ている。T.N.O.系の交献 によると，無然系から作っ た轼物泩，従来の撚系織物と同程度の強力を示すと報告 されている。

彷来，織物強力について，F.T.Peiceの研究“基盤

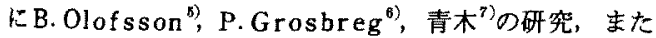
最近では丹羽，川端ら ${ }^{8}$ の一連の研究がある。いずれも 端物中の糸の荷重一伸長曲線を基本にし，これに構造の

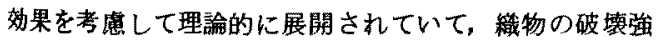
力は系强力によって支眍されるという考えに立脚してい る。これらの従来の理論は撚系織物については成立する が，無㜣系織物については，無撚采自身に強力はほとん どないので，その考えをそのまま無然系織物の破壊強力 に道用することはできない。

本報で注，無然系織物の作成とその破壊強力について
考察した。糸の撚俰数のみ翼なり他の条件は同じ二種類 の然糸䄳物を作成した。とくに，無撚䒺織物の破壊胎力 について理論的に考察した。無然糸織物の無張力状態と

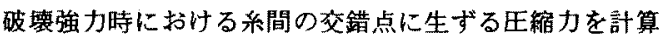
した。その压樎力と糸強力の関係式より，無然釆織物の 釆1本あたりの強力を計算し，その計算値と㬰験值を比 較検討した。

\section{2. 試料の作成}

\section{1 药}

原料は瀻維長 $51 \mathrm{~mm}$ (等長)，瀻度 $2 \mathrm{~d}$, 強力 $4.1 \mathrm{~g}$, 伸度 $24.1 \%$ \%゙スコースレーヨンで粗䊉機上りの粗糸 （1.5番手）を用いた。

無撚夈は图 1 の無撚系作成装置により作成した。紡出 番手は 20'sである。精紡機のフロントローラーからでた 織維束は空気による取束器で丸められる。そして，雺吹 器により $5 \%$ P.V.A.溶液を状にして，5７\%纎維 束に吹きつける。その後、ドライヤーで乾蜗し, 巻取口 ーラーで巻取る。 


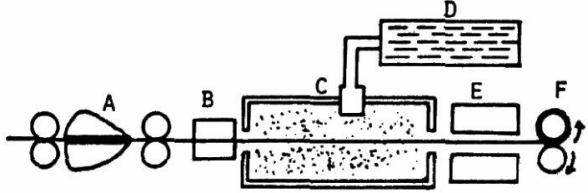

Fig. 1 Apparatus for the production of twistless yarn.

(A:Drafting part, B:Convergenter,

C:Sprayer, D: 5\% P. V.A. solution,

$\mathrm{E}:$ Dryer, and $\mathrm{F}:$ Twistless yarn.)

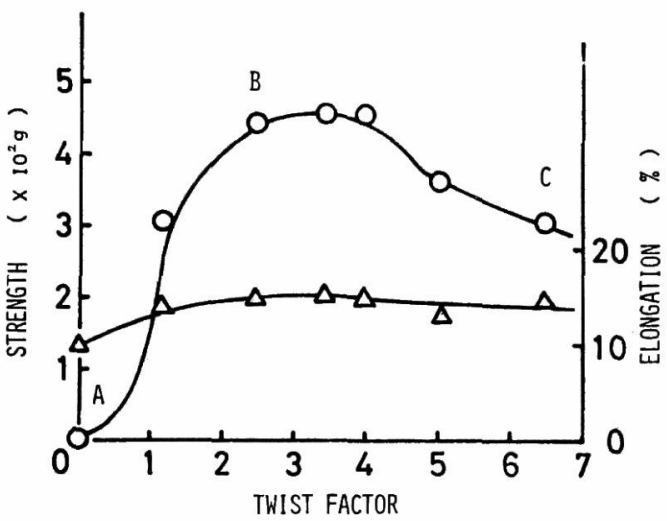

Fig. 2 Properties of $20^{\prime s}$ yarns with various twist factors.

$-\mathrm{O}-\mathrm{O}-$ : Strength, $-\Delta-\Delta-:$ Elongation, A $: T_{0}$ Yarn, B $: T_{25}$ Yarn, and C $: T_{6}$ Yarn.

撚系には従来のリング精紡機を用いた。これらの糸の

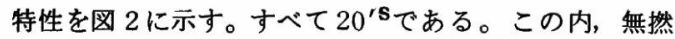
米および撚係数が $2.5 ， 6.5$ の 2 種類の然系を実験対象 として選び，それぞれ $T_{0}$ 糸， $T_{25}$ 系， $T_{6.5}$ 糸と名づける。 $T_{0}$ 釆は無撚糸, $T_{25}$ 釆は普通の撚をもった撚系, $T_{0.5}$ 禾 は強撚の撚系である。

$T_{0}$ 糸（糊付）と $T_{25}$ 系のセリプレーンを図 3 に示す。 また, $T_{0}$ 糸， $T_{25}$ 系， $T_{\mathrm{Bb}}$ 糸の種々の等性を表 1 に，そ の荷重一伸長曲線を図 4 に示す。系の引張り試験は, 試

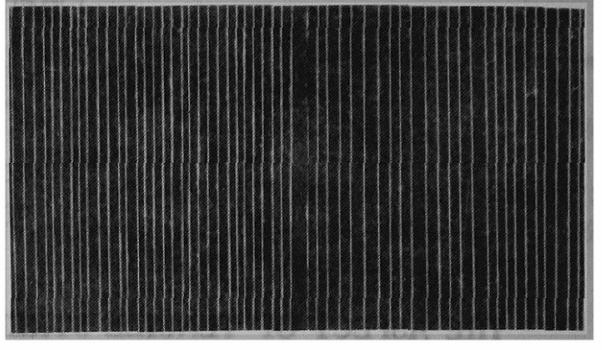

(a)

(b)

Fig. 3 Seriplane of $T_{0}$ Yarn and $T_{2 \delta}$ Yarn.

(a) To Yarn with P.V.A. (Twistless Yarn )

(b) $T_{25}$ Yarn (Normal Twist Yarn)

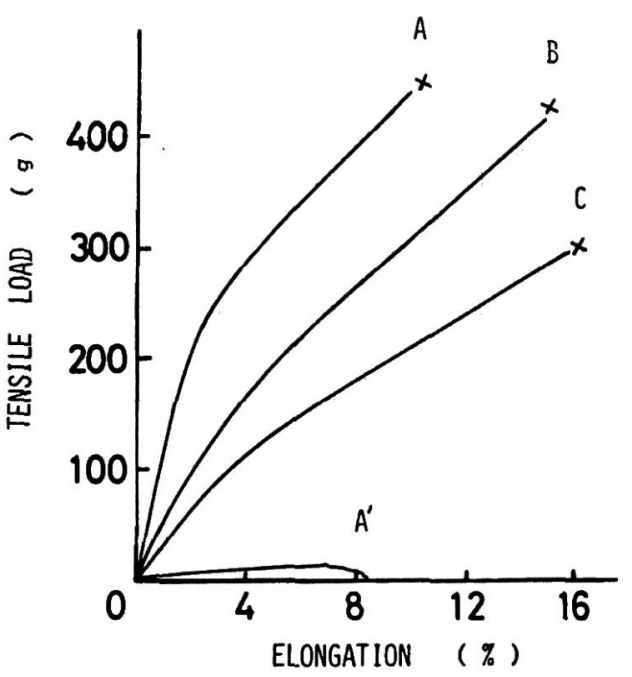

Fig. 4 Load-elongation curves of $T_{0}$ Yarn, $T_{25}$ Yarn and $T_{0.5}$ Yarn.

(A: $T_{0}$ Yarn with P.V.A., A': $T_{0}$ Yarn without P.V.A., B : $T_{25}$ Yarn, C: $T_{65}$ Yarn, and $X:$ Breaking point.)

Table. 1 Yarn Properties.

\begin{tabular}{|c|c|c|c|c|c|c|}
\hline & $\begin{array}{c}\text { Yarn } \\
\text { Count } \\
\text { ('s) }\end{array}$ & $\begin{array}{r}\text { Twist } \\
\text { Factor } \\
\end{array}$ & $\begin{array}{c}\text { Evenness } \\
(\mathbf{u} \%)\end{array}$ & $\begin{array}{c}\text { Yarn } \\
\text { Strength } \\
\left(\begin{array}{c}\mathrm{g} \\
\text { ) }\end{array}\right)\end{array}$ & \begin{tabular}{|c|} 
C. V. of Yarn \\
Streng th \\
( $\%$,
\end{tabular} & $\begin{array}{c}\text { Elongation } \\
\left(\frac{p}{0}\right)\end{array}$ \\
\hline $\begin{array}{c}T_{0} \text { Yarn } \\
\text { with P.V.A. })\end{array}$ & 20 & 0 & 12.0 & 450 & 9.8 & 10.4 \\
\hline $\begin{array}{c}T_{0} \text { Yarn } \\
\text { (without P.V.A.) } \\
\end{array}$ & & 0 & & 3.5 & & 7.8 \\
\hline$T_{2 b}$ Yarn & 20 & 2.6 & 12.5 & 426 & 12.1 & 15.2 \\
\hline$T_{Q, 5}$ Yarn & 20 & 6.4 & 12.3 & 314 & 15.5 & 16.1 \\
\hline
\end{tabular}


長 $10 \mathrm{~cm}$,引張り速度 $100 \mathrm{~mm} / \min$ で各 30 回づつ行 なった。表 1 , 図 4 より, $T_{0}$ 系（糊付）は $T_{25}$ 夈, $T_{0.5}$ 系と比較して, 強力, 強力の変動係数, 伸度の点から, 経系としても使用でき, 経系糊付の必要もない。

\section{2 織物}

手織織機を用いて製織した。 $T_{0}$ 禾， $T_{25}$ 糸， $T_{65}$ 糸の 各平織物をそれぞれ $T_{0}$ 系織物, $T_{25}$ 糸織物, $T_{6.5}$ 糸織物 と名づける。経系, 緯系ともに 17 本 $/ \mathrm{cm}$ の系密度の $T_{0}$ 糸織物, $T_{25}$ 糸織物, $T_{6.5}$ 杀織物を製織した。また, 経 糸密度は 17 本 $/ \mathrm{cm}$ と一定にし, 緯系の打ち込み本数 を変えて種々の采密度の $T_{0}$ 糸織物と $T_{2 \sigma}$ 系織物を製織し た。製織の際, $T_{25}$ 糸と $T_{65}$ 糸は経糸糊付の必要があり， P.V.A.を糊材として使用した。製織後， 3 種類の䅉物 がともに同じ条件になるように, 温水中で $2 \cdot 3$ 回もみ

Table. 2 Yarn Density in the Fabric (no. $/ \mathrm{cm}$ )

\begin{tabular}{|r|l|l|c|c|c|}
\hline \multicolumn{2}{|c|}{$T_{0}$ Fabric } & \multicolumn{2}{c|}{$T_{25}$ Fabric } & \multicolumn{2}{c|}{$T_{6.5}$ Fabric } \\
\hline Warp & Wef t & Warp & Wef t & Warp & Wef t \\
\hline 17.0 & 17.0 & 17.0 & 17.0 & 17.0 & 17.0 \\
\hline
\end{tabular}

\begin{tabular}{|c|c|c|c|c|}
\hline \multirow{2}{*}{ Sample } & \multicolumn{2}{|c|}{$T_{0}$ F abric } & \multicolumn{2}{c|}{$T_{2 \text {. }}$ Fabric } \\
\cline { 2 - 5 } & Warp & Wef p & Warp & Wef t \\
\hline No. 1 & 17.0 & 5.0 & 17.0 & 10.5 \\
\hline No. 2 & 17.0 & 9.0 & 17.0 & 14.0 \\
\hline No. 3 & 17.0 & 15.0 & 17.0 & 17.5 \\
\hline No. 4 & 17.0 & 20.0 & 17.0 & 20.0 \\
\hline No. 5 & 17.0 & 24.0 & 17.0 & 25.0 \\
\hline
\end{tabular}

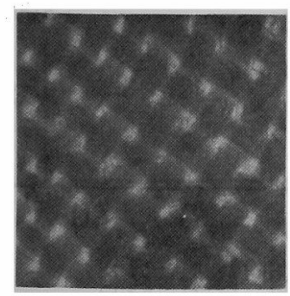

(a)

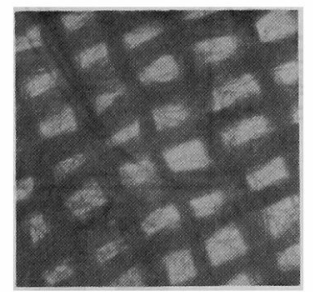

(b)

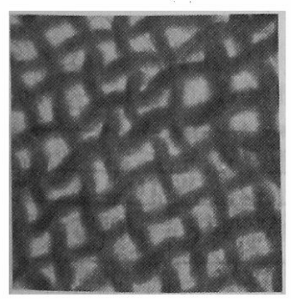

(c)

Fig. 5 Microphotographs of $T_{0}$ Fabric, $T_{25}$ Fabric, and $T_{6,5}$ Fabric. $(\times 20)$
(a) $T_{0}$ Fabric (b) $T_{25}$ Fabric

(c) $T_{\mathrm{as}}$ Fabric
洗いして糊抜きを行なう。糊抜き後の $T_{0}$ 米織物から夈を ていねいにほぐして, その強力を調べた結果, 約 $3.5 \mathrm{~g}$ であった。織物中の亲密度を表 2 に示す。

$T_{0}$ 糸織物, $T_{25}$ 糸織物, $T_{6,5}$ 糸織物の代表的な顕微鏡 写真を図 5 に示す。

\section{3. 織物の引張りに関する結果および考察}

$T_{0}$ 系織物, $T_{25}$ 系織物, $T_{6.5}$ 糸織物の引張り試験をイ ンストロン型テンサイルテスターで行なった。試料の大

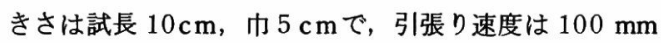
/minである。

$T_{0}$ 糸織物, $T_{25}$ 糸織物, $T_{65}$ 糸織物の同じ系密度の試 料の荷重一伸長曲線の 1 例を図 6 に示す。これより， $T_{0}$ 系自身にはほとんど強力がない（約 $3.5 \mathrm{~g}$ )にもかかわら ず，その織物は従来の撚糸織物と同程度の強力をもって いることがわかる。 $T_{65}$ 糸織物は過剩撚のため糸強力が 低く，そのため織物強力も低い。

つぎに, $T_{0}$ 糸織物と $T_{25}$ 糸織物の種々の糸密度の織物 を用いて, 引張り試験を行なった。 $T_{0}$ 系織物の経方向と 緯方向の荷重一伸長曲線を図 7 に示す。また $T_{25}$ 糸織物 の経方向と緯方向の荷重一伸長曲線を図 8 に示す。各織 物の破壊強力と破壊伸度を表 3 に示す。

$T_{0}$ 糸織物について, 低密度では破壊強力は低いが, 系 密度が增すにつれて破壊強力は高くなり, 緯方向では $T_{25}$ 糸織物の破壊強力と同程度あるいはそれ以上になる ことがわかる。低密度ではほとんどの㵶維がスッップし， 高密度では多くの織維が切断していることが観察された。

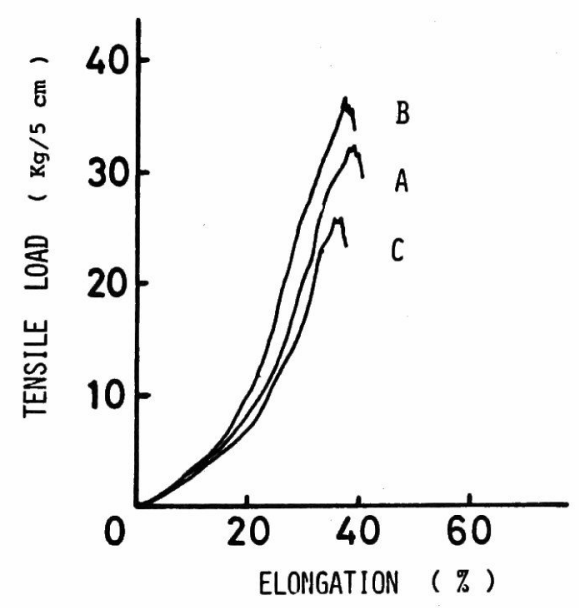

Fig. 6 Example of the Load-elongation curves of three kinds of fabrics. Each fabric has the same yarn density (A: $T_{0}$ Fabric, B: $T_{25}$ Fabric, and $\mathrm{C}: T_{6.5}$ Fabric ) 
これらの結果は織物中の采密度が変化しているので, 経方向と緯方向，また無撚系織物と撚杀織物の破壊強力 を正確に比較することはできない。そこで，各織物の破 壊強力を引張り方向の系本数で割った値，すなわち系 1 本あたりの織物强力を求めると，罒 9, 四 100ようにな る。图 9 は各織物を緯方向に引張った場合で，図10は各
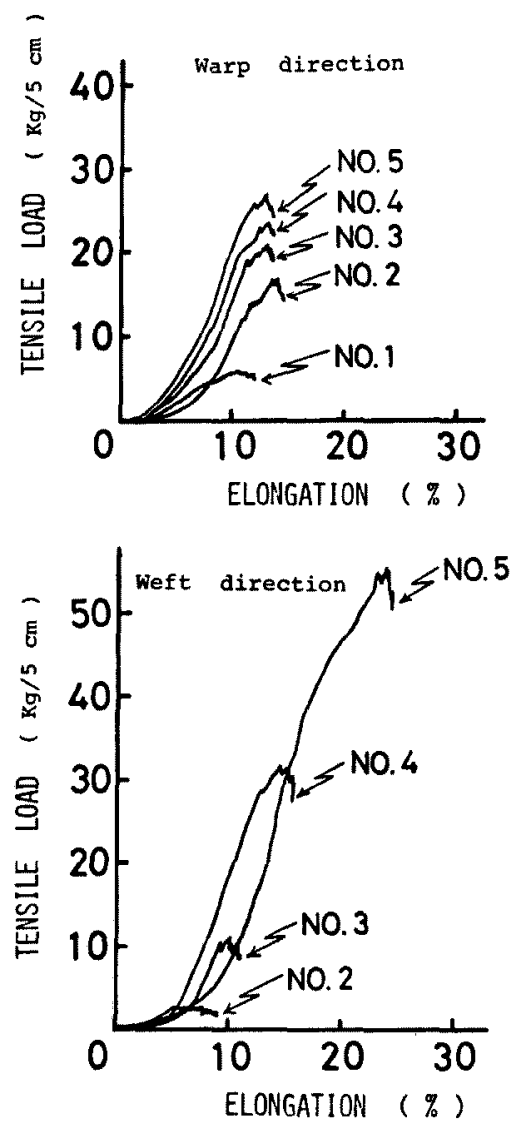

Fig. 7 Load-elongation curves of $T_{0}$ Fabric with various yarn densities.
織物を経方向に引張った場合である。この実紾では，製 織の㻮経系密度注一定で，緯系密度が变化している。 （表 3 参照）したがって，図9は引引張り方向に直交する 糸密度は一定で，引張り方向の系密度が变化する場合， また図10は引張り方向の系密度は一定で, 引張り方向に
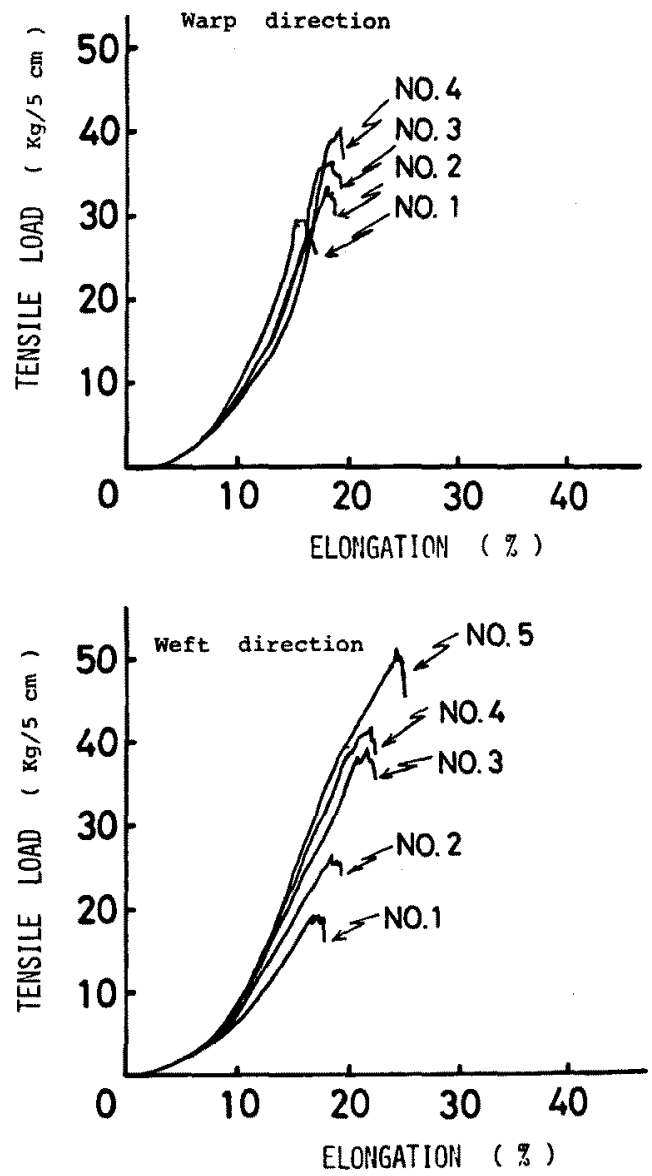

Fig. 8 Load-elongation curves of $T_{25}$ Fabric with various yarn densities.

Table. 3 Tensile Strength and Elongation

\begin{tabular}{|c|c|c|c|c|c|c|c|c|}
\hline \multirow{3}{*}{ Sample } & \multicolumn{4}{|c|}{$T_{\theta}$ Fabric } & \multicolumn{4}{|c|}{$T_{25}$ Fabric } \\
\hline & \multicolumn{2}{|c|}{ Warp } & \multicolumn{2}{|c|}{ Weft } & \multicolumn{2}{|c|}{ Warp } & \multicolumn{2}{|c|}{ Weft } \\
\hline & Strength & E longat $i$ ion & $\begin{array}{c}\text { Strength } \\
(\mathrm{kg})\end{array}$ & $\begin{array}{c}\text { Elongation } \\
(\%)\end{array}$ & $\begin{array}{c}\text { Strength } \\
(\mathrm{kg})\end{array}$ & $\begin{array}{c}\text { Elongation } \\
(\%)\end{array}$ & $\begin{array}{c}\text { Strength } \\
(\mathrm{kg})\end{array}$ & $\begin{array}{c}\text { Elongation } \\
(\%)\end{array}$ \\
\hline No. 1 & 6.01 & 10.22 & 0.84 & 2.50 & 31.45 & 18.02 & 19.24 & 16.54 \\
\hline No. 2 & 19.43 & 13.67 & 2.31 & 5.02 & 34.85 & 18.93 & 26.03 & 18.04 \\
\hline No. 3 & 20.82 & 11.02 & 10.24 & 10.03 & 38.67 & 19.52 & 39.60 & 22.32 \\
\hline No. 4 & 24.15 & 11.73 & 30.32 & 16.21 & 39.10 & 19.42 & 42.35 & 20.51 \\
\hline No. 5 & 25.70 & 12.00 & 52.65 & 24.32 & 36.97 & 18.53 & 50.40 & 25.52 \\
\hline
\end{tabular}


直交する糸密度か変化する場合のそれぞれの糸 1 本あた

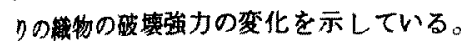

$T_{28}$ 糸䋘物の禾 1 本あたりの織物強力は, 糸密度が增 加してを破線て示した $T_{25}$ 釆の単系強力により多少大き 〈なる堹度である。（因 9，図10)一方， $T_{0}$ 米織物の米 1本ちたりの蟣物強力は，采密度の增加にともない急激 以高くなり， $T_{2 b}$ 系と同程度あるいはそれ以上になる。

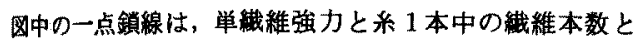
の措てあり， $T_{25}$ 采織物上りもむしろ $T_{0}$ 系織物の力が， この強力の極限值に近づくことがわかる。(因 9 )また， 团9 と图10を比較すると，因9のときは 2 次曲線的に 增加するのに対し，図10のときはほぼ直線的に增加し， ある一定值汇近づくことがわかる。

從来, 織物の荷重一伸長曲線について，荷重の小さい 初期の部分は，茟の曲げ䟝性の性質と織物構造(組織， 綡のワリンブなど)の性質を示し，荷重の大きい破壊強 力付近の部分は，物を構成する禾の性質を示すと考光 られている。これらに関しては，F.T.Peirceの研笢か

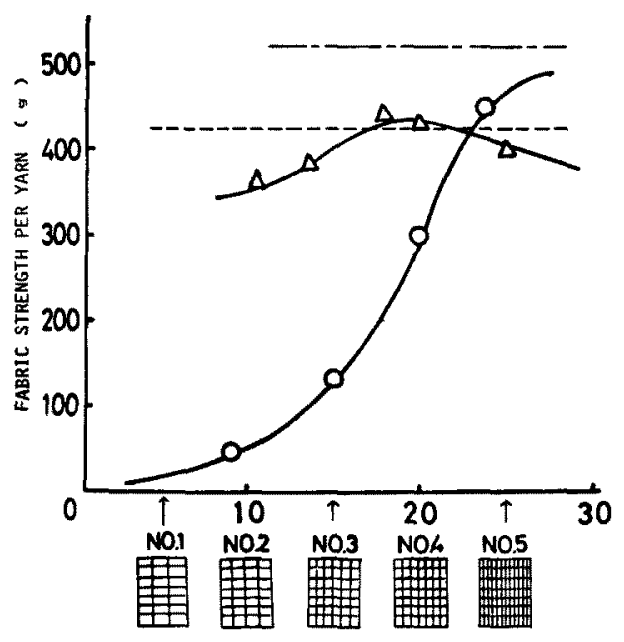

WEFT YARN DENSITY ( no./cm)

Fig. 9 Load strength per yarn of $T_{0}$ Fabric and $T_{25}$ Fabric. The fabrics are elongated in the weft direction. The fabrics used in this experiment are as shown in No. 1 $\sim$ No. 5. - their yarn densities vary in the tensile direction and are constant in the normal direction to it.

(-- The product of single fibre strength and the number of fibre per cross-section in a Yarn, -..-: $: T_{26}$ Yarn strength, $-\mathrm{O}-\mathrm{O}-\mathrm{O}-: T_{0}$ Fabric, and $-\Delta-\Delta-\Delta-: T_{2 s}$ Fabric.)

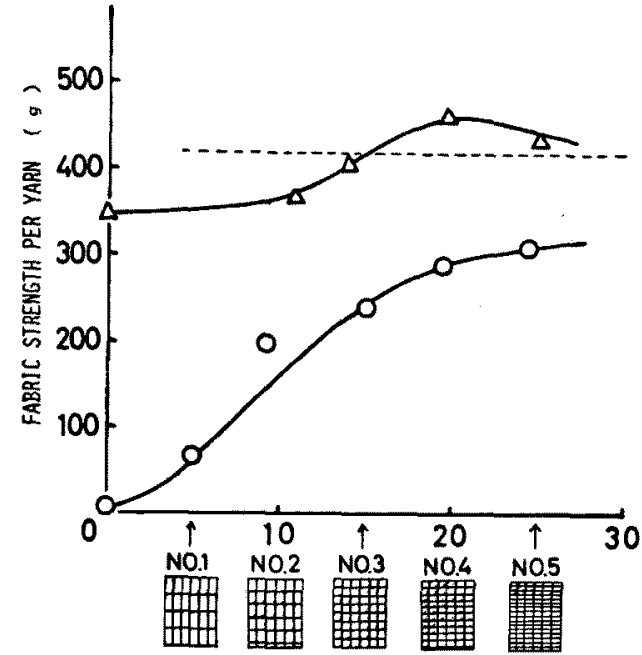

WEFT YARN DENSITY ( no./co )

Fig. 10 Fabric strength per yarn of $T_{0}$ Fabric and $T_{25}$ Fabric. The fabrics are elongated in the warp direction. The fabrics used in this experiment are as shown in No. $1 \sim$ No. 5 - their yarn densities are constant in the tensile direction and vary in the normal direction to it.

$\left(--: T_{25}\right.$ Yarn strength, $-\mathrm{O}-\mathrm{O}-: T_{0}$ Fabric, and $-\Delta-\Delta-: T_{25} F$ abric.)

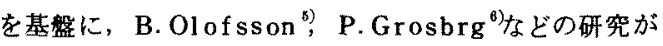
ある。とくに, 青木 ${ }^{7)}$ は糸の荷重 一伸長曲線がわかれば, 織物の荷重一伸長を求めることができると報告している。 また最近で注，丹羽・川端らによる“被服材料の力学的 性能に関する研究" ${ }^{8)}$ の中で，初期变形から破断点付近 までの織物の荷重一伸長曲線を理論的に求める式が提案 されている。これらの文城のいずれにおいても，低応力 の範囲で注織物の棈造が重要な因子として取扱われてい るが，破壊強力は糸強力に上って支配されるといら考え に立脚している。

$T_{25}$ 糸織物の破壞強力については, 図 9, 図100よ5 に徉来の考え方が適合できる。しかし， $T_{0}$ 糸織物の破 填強力については，T萧自身にはほとんど強力はない ので，従来の考え方をそのまま商用することはできない。 $T_{0}$ 系織物では，織物構造からくる䄉維間の摩摖力を考 える必要があると思われる。

\section{4. 無撚类織物の破壊強力の理論的考察}

T糸はほとんど強力をもたないのに，その儎物は従 来の燃糸絨物 ( $T_{26}$ 糸織物) と同程度の强力を示すのは， 引張り過珵における織物楆造の変形にともない，糸と糸 
の交錯点に圧絠力が発生し，そのため織維間の摩擦力が 増加するためであると考えられる。

つぎの仮定のもとに，T糸織物の破壊強力について考 察する。

（1）無張力状態において，織物中の経禾緯系の形態は 均一で，莱と糸の交錯点で正䈹力は存在しない。（図11

(a) )

（2）破壊張力時において，引張り方向の系はクリンプ がのびて，直線状態に近くなり，その糸軸は同一平面内 の位置を示すようになる。(図11（b）（c）

（3）破壊張力時に括いて，引張り方向に直交する米は 外側へ押し出され，かつわずかに伸ばされる(図11(b))

無張力時の $T_{0}$ 米紻物について，図 12(a)の上うに引張

( a

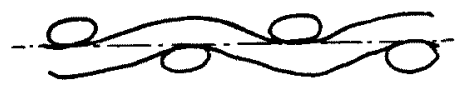

(b)

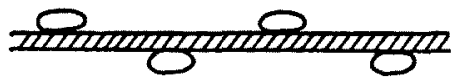

(c)

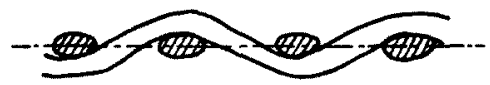

Fig. 11 Cross-section of the fabric

(a) Tensionless (b) Just before breaking (C.tting along the tensile direction) (c) Just before breaking (Cutting at the right angle to the tensile direction)

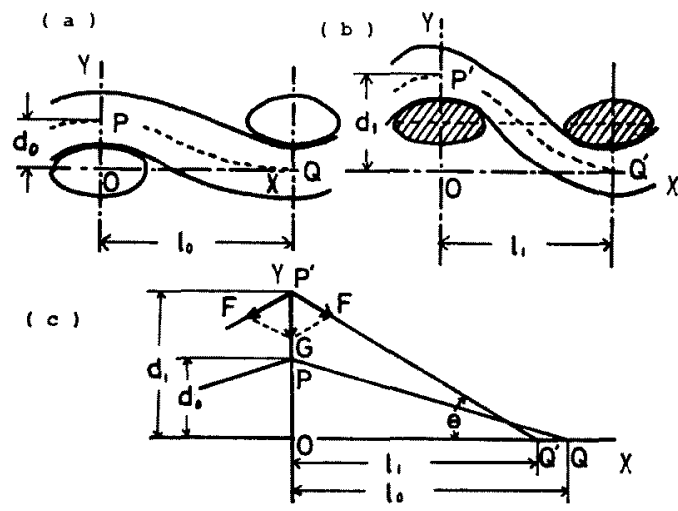

Fig. 12 Detail illustration of Fig. 11

(a) Tensionless (b) Just befor breaking

(c) Forces at the intersecting point.
ク方向の糸の中心に原点 0 をとり，引張り方向に直交す る禾の中心線(破線) とX栜，Y軸との交点を $P, Q$ と する。OPの長さを $d_{0} ， O Q の$ 長さを l。は各轿物について定まる值であり，維物の相密など によって翼なった値をとる。したがって，各䧽頼の藏物 について測定する必要がある。破装张力時において， は $l_{1}$ に， $d_{0}$ は $d_{1}$ に変化 $L ， P Q ， P^{\prime} Q^{\prime}$ を直線と考元る。

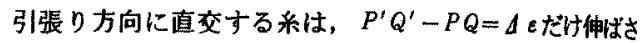
れ，この時生ずる力を $F$ とする。また破壊張力時におい

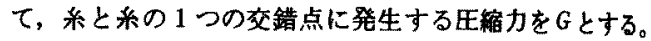
$F$ とGの関係は図 12 (c)より(1)式となる。

$$
G=2 F \sin \theta
$$

糸のヤング率を $E_{s}$ とすると， $F=\Delta \varepsilon \cdot E_{s} ，$ また図 12 (c) $上 \eta \Delta \varepsilon=P^{\prime} Q^{\prime}-P Q=\sqrt{\frac{l_{1}^{2}+d_{1}^{2}}{l_{0}^{2}+d_{0}^{2}}}-1$

$$
\begin{aligned}
& \sin \theta=\frac{d_{1}}{\sqrt{l_{1}^{2}+d_{1}^{2}}} \quad \text { となる。 } \\
& \text { したがって } \\
& G=2 \cdot d_{1} \cdot E_{s}\left(\frac{1}{\sqrt{l_{0}^{2}+d_{0}^{2}}}-\frac{1}{\sqrt{l_{1}^{2}+d_{1}^{2}}}\right)
\end{aligned}
$$

ここで $l_{1} / l_{0}=K_{1} \quad d_{1} / d_{0}=K_{2} \quad l_{0} / d_{0}=a$ とおいて, 整理すると。

$$
G=2 K_{2} E_{s}\left(\frac{1}{\sqrt{a^{2}+1}}-\frac{1}{\sqrt{a^{2} K_{1}^{2}+K_{2}^{2}}}\right)
$$

となる。

（3）式は，平䌦物を一軸方向に引張ったとき，破裹張力 時において，糸と糸の1つの交錯点に生ずる化䧴力を表 わす式である。

引張り方向の縖度を $M$ 本 $/ \mathrm{cm}$ とすると，次式が成 立する。

$$
\begin{aligned}
M & =1 / l_{0}=1 / a d_{0} \\
\therefore a & =1 / M d_{0}
\end{aligned}
$$

(3)(4)式より，GとMの開係を求めるために各因子の值 を炏の方法で実測した。

無張力状態と表 3 の各㵶物の破壊伸度寸前まで伸長し た状態の $T_{0}$ 糸織物をパラフィンで固定し，その保方向綪 方向の横断面を顕镜写真で観察した。その代表的な写 真を图 13 (a)(b)(c)に示す。（a)图上り仮定 (1)，(b) (c) 図より仮定 (2)(3)のようになっていることがわか る。これらの影竸写真より， $d_{0}, l_{0}, K_{1}, K_{8}$ の值を 求める。これらの值は織物の系密度などによって異なり， 表 $2 の 5$ 種類の $T_{0}$ 禾織物について求める。たとえば， 無張力状態のNo. 4 の試長について, $d_{0}=1.3 \times 10^{-8} \mathrm{~cm}$, $l_{0}=5.3 \times 10^{-2} \mathrm{~cm}$ であった。また $K_{1} ， K_{2}$ の值を求める ために， $d_{1}, l_{1}$ の值は，穖物の破壊強力を問还にして いるので，織物の破壊頻度の最も高い中央部に放いて唡 
定した。 $K_{1}, K_{2}$ の計算結果を図 14 に示す。 また $E_{s}$ の値 は $4.2 \times 10^{9} \mathrm{dyne} / \mathrm{cm}^{2}$ であった。各因子の値を代入して GとMの関保を求めると图15のようになる。このように 引豎り方向の糸密度の增加にともない破壊寸前の織物の 系と䋨の 1 つの交錯点に生ずる王縮力は，2次曲線的に 增加することがわかる。

域物中の引張り方向の采は，それに直交する系により 破壤寸前の状熊において，1つの交錯点でGなる王縮力 を受け，そのため織維間の摩擦力が增加する。そこで， 杫維間の摩擦力と系強力の関係式 (注参照) を適用して, 物中の引張り方向の系 1 本あたりの破壊強力を計算す る。

納の織䧽間の摩摖力 $(\Phi)$ と系強力 $(F)$ の関係式は次 式のようである。

$$
F=\frac{n L}{6} \Phi\left\{1-\left(1-\frac{4 f_{0}}{L \Phi}\right)^{3 / 3}\right\}
$$

$F:$ 采強力, $n:$ 平均断面緎維本数, $L:$ 平均㵶維 長, $f_{0}$ : 単瀻維強力, $\emptyset$ : 釆中の瀻維 1 本の単位長 さあたりの摩擦力

(5)式は， $\Phi=0$ のとき， $F=0 \quad \Phi=\infty$ のき， $F=$ nf。となる。Cox ${ }^{8)}$, Grosberg ${ }^{10)}$ によれば，瀻維束 中の1本の織維の引き抜き力は, 外正に比例し充実度に 反比例する。 $T_{0}$ 糸織物の破壊時に㧍いては， 5 種類の

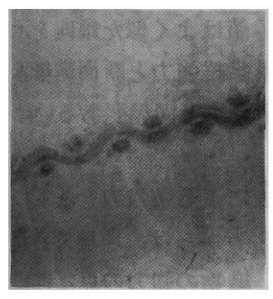

(a)

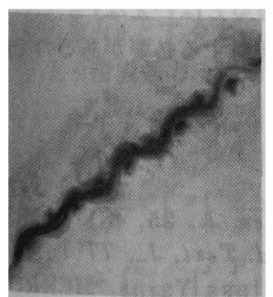

(c)

Fig. 13 Microphotographs of the Yarns in Fabric. $(\times 50)$, (a) Tensionless (b) Just before breaking ( $C$ utting al ong the tensile diretion)(c) Just before breaking (Cutting at the right angle to the tensile direction)
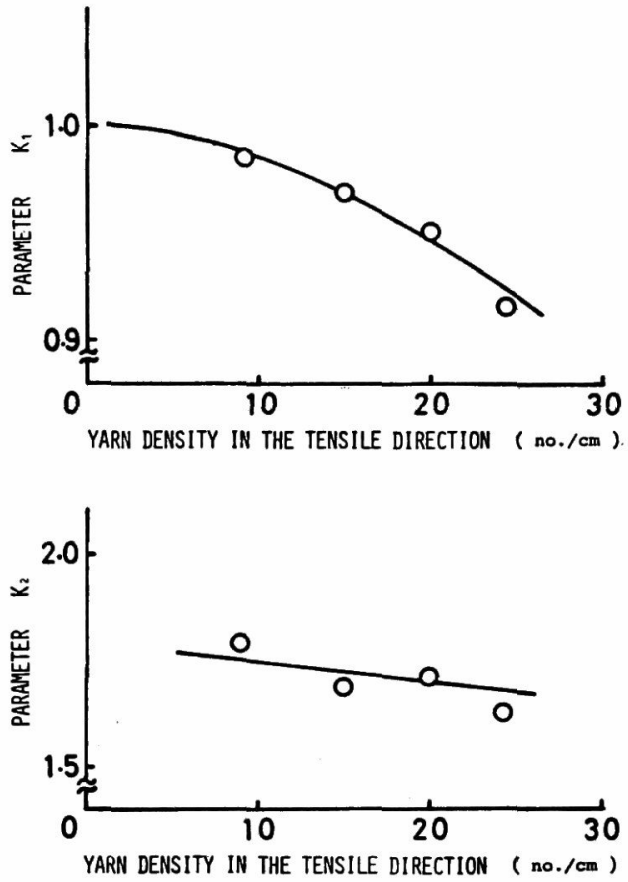

Fig. 14 Experimental values of parameter $K_{1}$ and $K_{2}$.

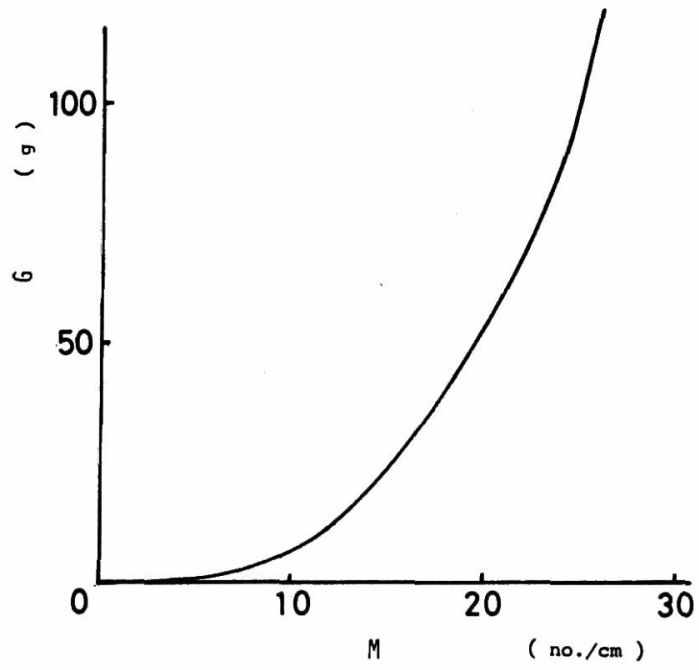

Fig. 15 Relation between $G$ and $M$. ( $G$ : the compressive force at once of the intersecting points of the yarns in fabric, $M$ : Yarndensity in the tensile direction.) 

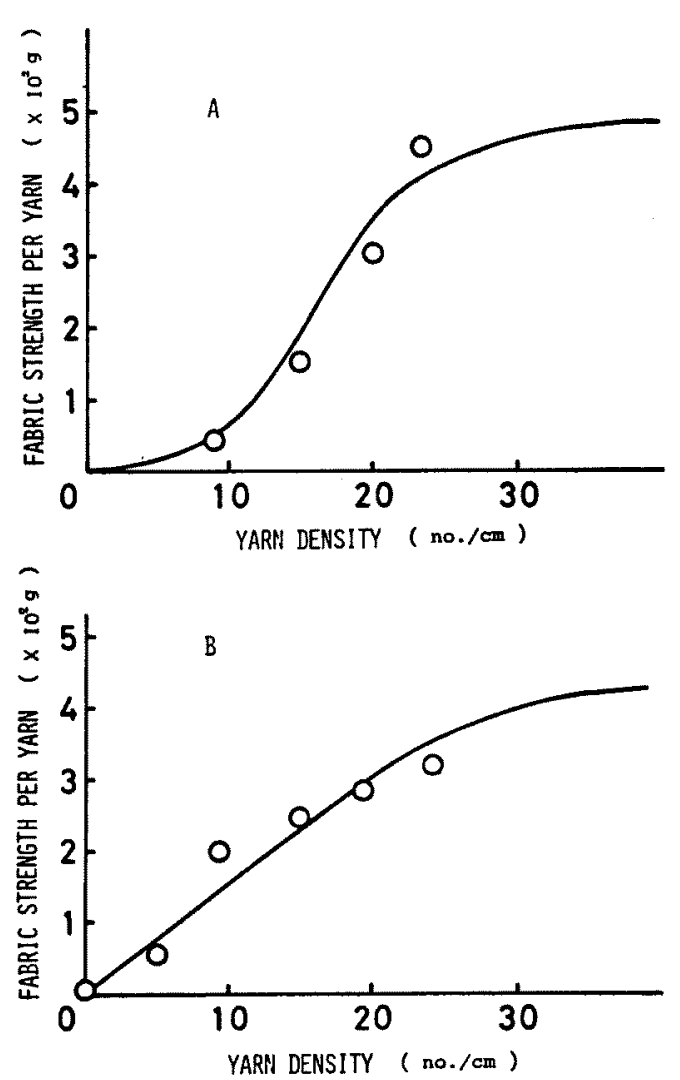

Fig. $16 \mathrm{C}$ omparison between the calculat ed values and the experimental values of the $T_{0}$ Fabric strength per Yarn. $A$ : Yarn density varies in the tensile direction. B: Yarn density varies in the normal direction to tensile. ( $O:$ Experimental, and - Calculated )

試料とも，充奉度は同じであると考えられる。ひっぱり 方向に直交する䒺密度を $N$ 本 $/ \mathrm{cm}$ とすると，外圠は $G$ $N(\mathrm{~g} / \mathrm{cm})$ となり，この外王を $n$ 本の纎維で支えてい ると考える。のとGの関係は次のようになる。

$$
\Phi=C G N / n
$$

$C$ は, 縅維の直径，表面状態などの䋐維の性質や，パッ キングなどの集合状態によって定まる值である。(6)式 の関俰を求めるために，T、系に種々の大きさの荷重を のせ，緎維 1 本の引き抜き実験を行なった。その結果， $G$ とФは直線関係にあり，Cの值は 0.83 となった。（5） （6）式に各因子の值， $n: 125$ 本， $L: 5.1 \mathrm{~cm}, f_{0}: 4.1 \mathrm{~g}$ と各 $M$ に対する $G$ の値，Nの值を代入して $F$ を計算した。 その計算結果と実験值の比較を図16に示す。図16 Aは, 引長り方向の糸密度が変化する場合の系 1 本あたりの織
物强力であり，図16Bは，引張り方向に直交する系密度 が変化する場合の糸 1 本あたりの織物虫力である。この ように計算值と史験值が大体一玫し，Aの場合，系1本 あたりの $T_{0}$ 系織物強力は 2 次的に增加し，単㳦䧴強力 と断面織維本数の積に近づき， $\mathrm{B}$ の場合，直線的に增加 しある值（Gの值によって決まる。）に近づく。

\section{5. 結言}

試作した装圈により，無撚系を作成した。また，無热 糸織物と系の撚係数のみ異なり他の条件は同じ2種類の 然杀織物を製織した。それらの織物の強力について考察 した結果，次のようなことが明らがなった。

(1) 無然系織物について，無撚系自身はほとんと強力 をもたないのに，普通以上の采密度の織物では，従来の 撚䒺織物と同程度あるいはそれ以上の破壊強力を示す。

（2）系1本あたりの織物強力について，無热系織物と 然䒺織物を比䡈すると，前者は蟣物棈造の効果が大きく 影锌するのに対し，後者はあまり影稫されない。

（3）従来，織物の破䧇強力はほとんど糸強力によって 支配されると考えられており，この考えから(1)(2)の無 撚杀織物特有の破壊强力を説明することはできない。無 撚糸織物の場合, 引張り過程に拉ける樴物構造の变形に ともない，系間の交錯点に王縮力が発生し，紻維間の摩 擦力が増加するためであると考えられる。この考えをも とにして計算した計算值と実験値はよく似た傾向を示す。 （4）織物強力の限界である単織維強力と断面織維本数 の積の値に，無撚釆織物も撚糸織物と同程度あるいはそ れ以上に近づく㖽向がある。

以上のように，普通の試験法による系強力を基本にし た従来の織物強力に対する考え方からは，理解できない 興味ある $2 \cdot 3$ の結果を得た。織物の強力の点だけにつ いていえば，系強力を最大にする撚数すなるち系の最啇 撚数が織物中の撚の最薏值であるとはいえない。このこ とから織物中の然の意義を再検討する必要があるのでは ないかと考えられる。

文献

1) R. D. Weels; Text. Res. J., 25, 481 (1955)

2) E. Bobkowicz; Canad. Text.J., 77 (1970)

3) H. J. Selling ; Twistless Yarns, MERROW (1971)

4) F. T. Peirce; J.Text. Inst., 28, T 45 (1937)

5) B. Olofsson; J.Text. Inst., 55, T 541 (1964)

6) P. Grosberg; J. Text. Inst., 57, T 383 (1966)

7) 青木; 織学誌., 4, 132 (1948) 
8) 丹羽, 川端, 河合 ; 䄉学誌., 19, T 157 (1966) 20, T 12 (1967) 20, T 258 (1967) 20, T $279(1967) \mathbf{2 0}$, T 317 (1967)

9) L. J. Postle, J. Ingham and D. R. Cox ; J. Text. Inst., 43, T 77 (1952)

10) P.Grosberg; J. Text. Inst., 54, T 223 (1963)

11）三平，黑崎，渡讱；䄉稚学会要旨集 p.84(1968)

12) V.B.Merchant ; J. Text. Inst., 51, T 58 (1963)

(注)

昭和 43 年織䧽学会秋期大会（要旨集p. 84 87) で “統力を目標とした糸体設計に関する一考察”（三平， 黑䓫, 渡沉 $)^{11)}$ と題して発表したものの一部である。こ こでは，莱強力の理論式についてのみ記載する。

長さ $L$ 等長織維の絬績禾のスライバー線図が图 17 のように表わされ，XX面で織䧴本数が最小であるとす る。Marchant ${ }^{13)}$ によれば，系強力は $X X^{\prime}$ 面を横切って いる各䄉維が，系の引張りに祭してXX'で生ずる仙力の 合計として表わされる。そして，XX'面の各㵶維のもつ

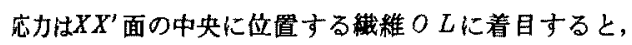
その臷維の長さに沿って生ずる応力分布に等しいと考え られる。スライパー線図中に $x$ 軸 $y$ 軸を考元，XYの把 持曲線を $P(x)$ とすると， $Y^{\prime} X^{\prime}$ の把持曲線は $P(X+L)$ となる。そして, Marchant ${ }^{12)}$ は粗糸の引張りの祭, 緎 維 0 Lにお打応力分布を(1) 式で表わした。

$f(x)=\Phi \int_{0}^{x} P(x)+P(x+L) / P(x)-P(x+L) d x$ (1) いま $0<x<L の$ 籁囲で, $f(x)$ の最大值を $f \max$ とす ると， $f \max$ が単繊維強力 $f_{0}$ より小であれば， 来の $X$

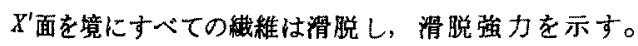

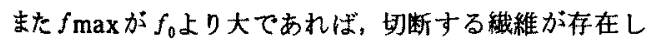
一般の紡續系沬これに属する。そこで， $f(x)=f_{0}$ となる $x$ の値をL $L_{B}$ とすと，系強力は次式で表わされる。

$F=$ 滑脱強力十切断強力

$$
\begin{aligned}
& =\left[\int_{0}^{L_{B}} f(x) d x+\int_{L-L_{B}}^{L} f(x) d x+f_{0}\left(L-2 L_{B}\right)\right] \times \frac{n}{L} \\
& =\frac{n \emptyset}{L}\left[\int_{\theta}^{L_{B}} \int_{0}^{x} \frac{P(x)+P(x+L)}{P(x)-P(x+L)} d x d x\right. \\
& \left.+\int_{L-L_{B}}^{L} \int_{0}^{x} \frac{P(x)+P(x+L)}{P(x)-P(x+L)} d x d x\right]
\end{aligned}
$$

$+\frac{n \emptyset}{L}\left(L-2 L_{B}\right)$

$d x$ : 践維 $O L$ を分割した敬少な要素長， $\emptyset: 1$ 本の 䄉維の単位長さあたりの摩摖力, $f_{0}$ : 緎䧽強力, $L_{B}$ : 滑脱と切断の限界の $x$ 值, $n$ : 平均断面紻維 本数

䄉維が理想的に配列している紡精系について，(2)式 を解く。把持曲線は，

$$
P(x)=-\frac{n}{L} x+n, \quad P(x+L)=-\frac{n}{L} x
$$

となる。(1) 式は, $f(x)=\emptyset \int_{0}^{x}\left(1-\frac{2 x}{L}\right) d x$

となる。また $f(x)=f_{0}$ となる $x$ の值 $\left(L_{B}\right)$ は，

$$
L_{B}=\frac{L}{2}\left(1-\sqrt{1-\frac{4 f_{0}}{L \Phi}}\right)
$$

となる。そして, $f_{\max }=\frac{L \emptyset}{4}$

となる。（2）式に（4)，(5) 式を代入して，糸強力 $F を$ 求めると(7) 式となる。

$$
F=\frac{n L}{6} \Phi\left\{1-\left(1-\frac{4 f_{0}}{L \Phi}\right)^{3 / 2}\right\}
$$

（根号内が負になる場合は，すべての織維が滑脱する ことを意味する。)

(i) $4 f_{0} / L \Phi \geq 1$ とき, 糸中の全緉維が滑脱する。 このとき， $F=n L \emptyset / 6$ となり， $\phi=0$ ととき, $F=0$ となる。

(ii) $4 f_{0} / L \Phi<10$ とき，系中の 1 部の瀻維が切断す

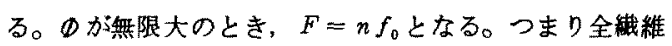

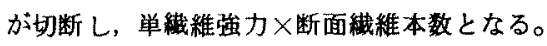

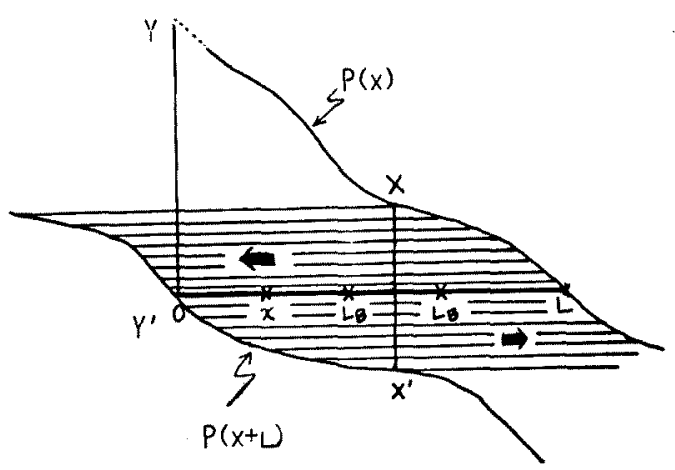

Fig. 17 Sliver Diagram 